\title{
The Drabo corymbosae-Papaveretea dahliani - a new vegetation class of the High Arctic polar deserts
}

\author{
Fred J. A. Daniëls ${ }^{1, *}$, Arve Elvebakk ${ }^{2}$, Nadezhda V. Matveyeva ${ }^{3}$ \& \\ Ladislav Mucina ${ }^{4}$
}

Keywords: Arctic subzone A, Arctic cushion forb subzone, biogeography, High-Arctic polar desert, Papaverion dahliani, patterned ground, syntaxonomy, zonal vegetation.

Ključne besede: arktična podcona A, arktična podcona blazinastih zelišč, biogeografija, visoko arktična polarna puščava, Papaverion dabliani, strukturirane talne oblike, sintaksonomija, conalna vegetacija.

Received: 13. 2. 2015

Revision received: 8. 6. 2015

Accepted: 11. 6. 2015

\begin{abstract}
A new class and a new order (Drabo corymbosae-Papaveretea dabliani and Saxifrago oppositifoliae-Papaveretalia dahliani) have been described, and the Papaverion dabliani validated. This is vegetation of zonal habitats in lowlands of the High Arctic subzone A (or Arctic herb, cushion forb or polar desert subzone) and of ecologically equivalent sites at high altitudes on the mountain plateaus of the High Arctic. The new class spans three continents - North America (Canadian Arctic Archipelago and Greenland), Europe (parts of Svalbard and Franz Josef Land), and Asia, including northern regions of Chelyuskin Peninsula (Taymir Peninsula), Severnaya Zemlya Archipelago and De Longa Islands.
\end{abstract}

\begin{abstract}
Izvleček
Opisali smo nov razred in red (Drabo corymbosae-Papaveretea dahliani in Saxifrago oppositifoliae-Papaveretalia dahliani) in validirali zvezo Papaverion dabliani. To je conalna vegetacija v nižinah visoke artktične podcone A (ali arktična zelišča, blazinaste zelišča ali polarna puščavska podcona) in ekološko enakovredna rastišča na višjih nadmorskih višinah na gorskih platojih visoke Arktike. Nov razred je razširjen na treh kontinentih - Severni Ameriki (kandski arktični ahipelag in Grenlandija), Evropi (deli Svalbarda in Dežela Franca Jožefa) in Aziji vključno s severnimi deli polotoka Chelyuskin (polotok Taymir), arhipelag Severnaya Zemlya in otoki De Longa.
\end{abstract}

Nomenclature of plants and fungi: Nomenclature of vascular plants follows the checklist by Elven et al. (2014), while the nomenclature of lichens and bryophytes follows Elvebakk \& Hertel (1996) and Frisvoll \& Elvebakk (1996), respectively. Exceptions are Scapania crassiretis Bryhn, Siphula ceratites (Wahlenb.) Fr. and Sticta arctica Degel., that have not been included in the checklists listed above.

\footnotetext{
1 Institute of Biology and Biotechnology of Plants, University of Münster, Schlossplatz 8, D-48143, Münster, Germany. E-mail: daniels@uni-muenster.de *Corresponding author

2 Tromsø University Museum, University of Tromsø - Arctic University of Norway, N-9037 Tromsø, Norway. E-mail: arve.elvebakk@uit.no

3 Komarov Botanical Institute, Russian Academy of Sciences, 2 Prof. Popova Street, St. Petersburg, Russian Federation. E-mail: nadya_mat@mail.ru

4 Iluka Chair in Vegetation Science and Biogeography, School of Plant Biology, The University of Western Australia, 35 Stirling Hwy, Crawley WA 6009, Perth, Australia. laco.mucina@uwa.edu.au; Department of Geography \& Environmental Studies, Stellenbosch University, Private Bag X1, Matieland 7602, Stellenbosch, South Africa; Department of Botany and Microbiology, College of Science, King Saud University, P.O. Box 2455, Riyadh 11451, Saudi Arabia.
} 


\section{Introduction}

The terrestrial Arctic territory is bio-climatically subdivided into five subzones (CAVM Team 2003; Walker et al. 2005). The smallest and northernmost Subzone A, that is also known as 'Arctic Herb Zone' (e.g. Daniëls et al. 2000), 'Arctic cushion forb subzone' (e.g. Walker et al. 2002), 'Arctic Polar Desert Zone' (e.g. Elvebakk 1985, Bay 1997), 'Arctic polar desert' (e.g. Aleksandrova 1988, Matveyeva 2006) and High Arctic Tundra (Yurtsev 1994), is strongly influenced by the Arctic Ocean. It includes the Canadian Sverdrup Islands and mainly comprises the northernmost fringes of Greenland and Eurasia as well as islands of the Arctic Ocean such as parts of Svalbard, Franz Joseph Land, Severnaya Zemlya and De Longa Islands (CAVM Team 2003, Walker et al. 2005). Plant growth is confined by a very cold climate with low mean July temperature of less than $3^{\circ} \mathrm{C}$ and low summer warmth index (SWI; the sum of monthly mean temperatures exceeding $0^{\circ} \mathrm{C}$ ) of less than $6^{\circ} \mathrm{C}-$ an indicator of the total amount of summer warmth supportive of plant growth (Young 1971). Permafrost and cryoturbation result in patterned-ground forms both fine grained and gravelly deposits in the lowlands, whereas frost cracking of bedrock induces formation of screes, stone and boulder fields and of stony plateaus at higher altitudes. Habitat differentiation is less pronounced than in the other two southern High Arctic Subzones B and $\mathrm{C}$ and in the Low Arctic Subzones D and E (for more details and discussion of the ambiguous nomenclature of the Arctic subzones see Aleksandrova 1988, Matveyeva 1994, 1998, 2006, Bliss 1997, Elvebakk 1997, Walker et al. 2005, 2008, Chernov et al. 2011).

The Subzone A is botanically characterised by occurrence of only 100-120 vascular plants species (Elven et al. 2014, Daniëls et al. 2013). Around 100 species of vascular plants occur in the Russian Arctic polar desert (cf. Aleksandrova 1988, Chernov et al. 2011, Matveyeva \& Zanokha 2015). Twenty-five species, or about $20 \%$ of the total Subzone A flora, occur all around the polar desert subzone A with more than $80 \%$ frequency. These taxa include Alopecurus borealis, Cardamine bellidifolia, Cerastium arcticum, C. regelii, Cochlearia groenlandica, Draba corymbosa, D. micropetala, D. pauciflora, D. subcapitata, Luzula confusa, L. nivalis, Micranthes nivalis, Papaver dablianum, Phippsia algida, Poa abbreviata, P. arctica, Poa pratensis subsp. alpigena, Potentilla hyparctica, Puccinellia angustata, Ranunculus sulphureus, Saxifraga cernua, S. cespitosa, S. hyperborea, S. oppositifolia and Stellaria longipes s.l.). In local floras of the Subzone A the species count of vascular plants is about 50 . They are not abundant and occur scattered, usually as single specimens.

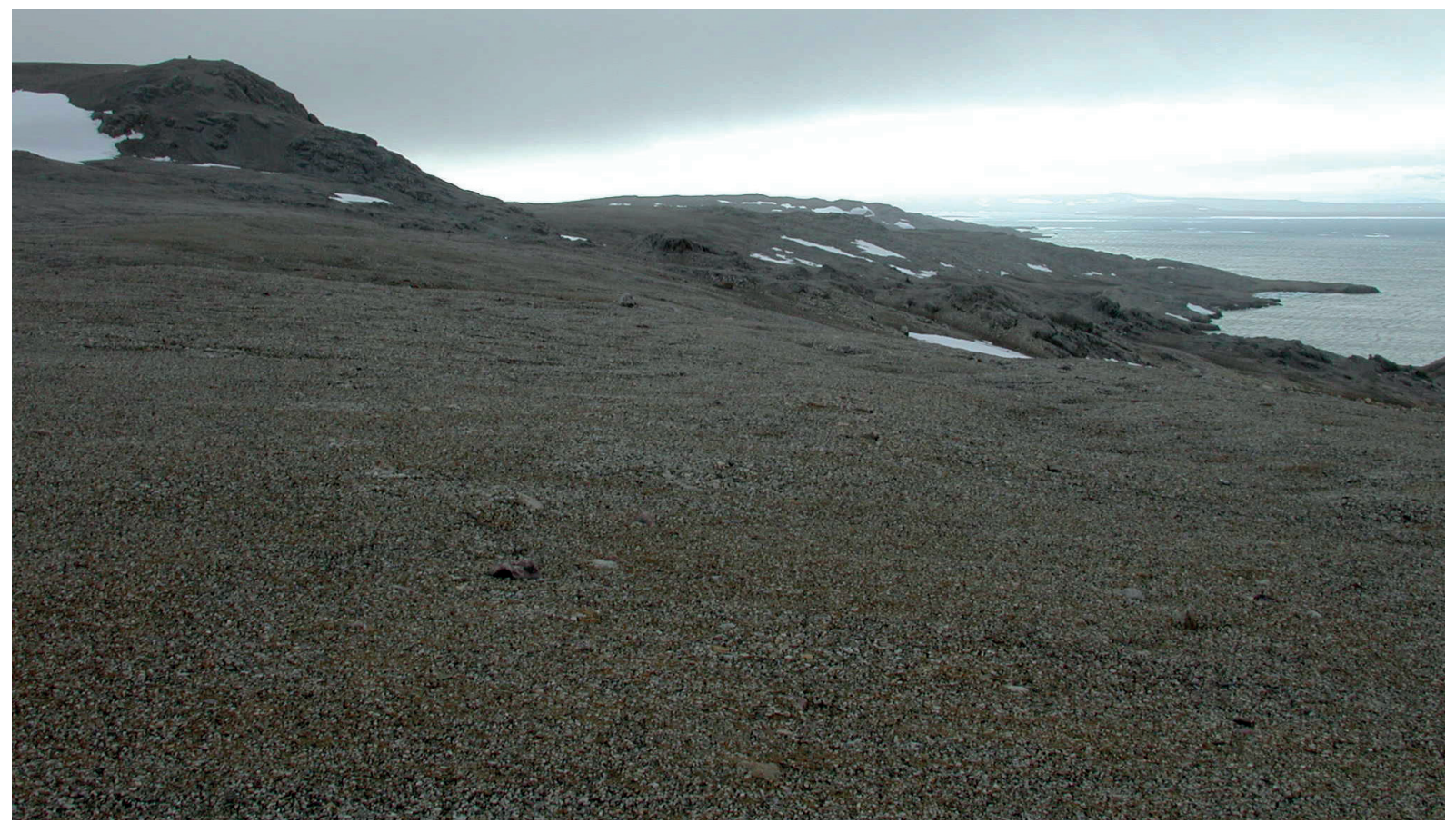

Figure 1: Polar desert vegetation and landscape at Kinnvika, Nordaustlandet, Svalbard, $80^{\circ} \mathrm{N}$. The limestone landscape appears to be sterile, but ca. 20 vascular plant species are regularly scattered over the area. Photo: A. Elvebakk, July 2005.

Slika 1: Polarna puščava in krajina pri Kinnvika, Nordaustlandet, Svalbard, $80^{\circ} \mathrm{N}$. Apnenčasta krajina izgleda sterilna, vendar se je 20 vrst redno pojavlja raztreseno po območju. Foto: A. Elvebakk, julij 2005. 
Subzone A is not always dry and sparsely vegetated or desert-like (Figure 1,2), but it can be very moist and rather continuously vegetated as for instance in Franz Josef Land (Figure 3). This is why some authors (e.g. Tedrow 1977, Yurtsev 1994, Walker et al. 2002) did not consider 'polar desert' an appropriate term for this subzone.

The vegetation of the polar desert subzone includes open ('desert-like') to rather dense (tundra-like) zonal vegetation in more mesic sites, whereas plant cover is dense in intra-zonal wetlands and snowbed communities. The Subzone A is furthermore characterised by absence of dwarf shrubs and woody plants, sedges (Carex) and bog mosses (Sphagnum), the absence of peat in wetlands and local predominance of cushion forbs, bryophytes, crustose lichens,

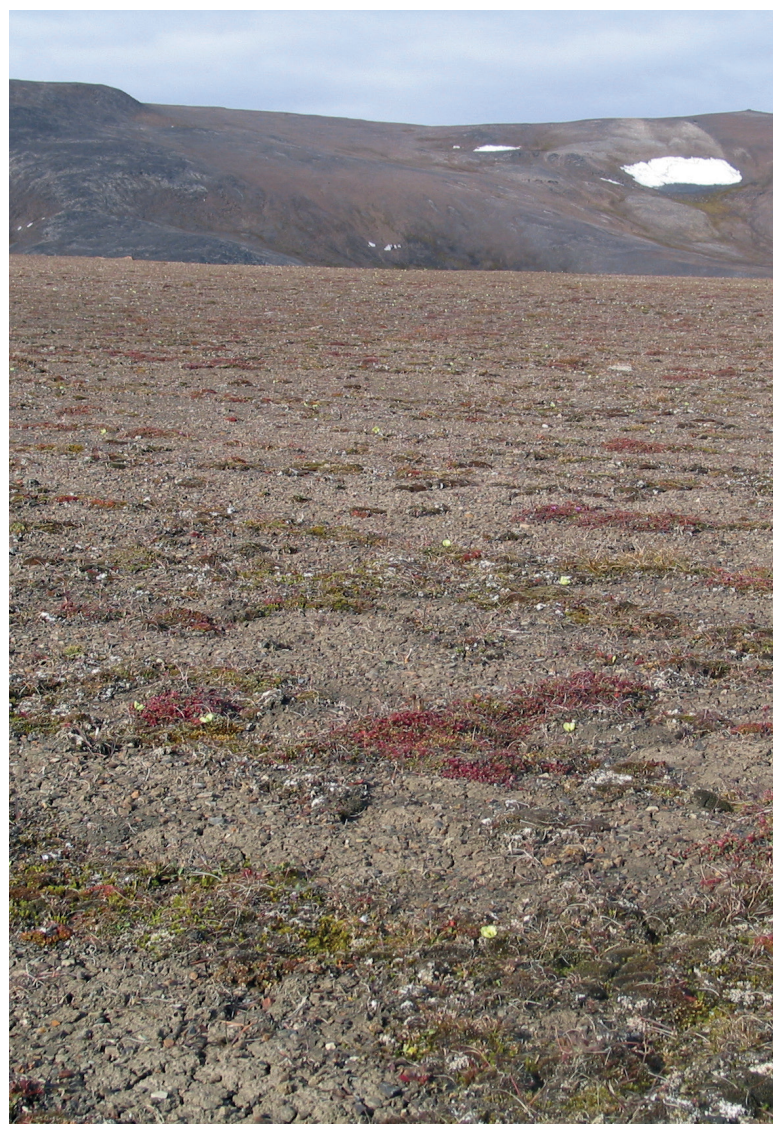

Figure 2: General view of the Drabo-Papaveretea vegetation with Micranthes foliolosa, Papaver dahlianum (yellow spots), Saxifraga oppositifolia, S. cespitosa, mosses and lichens. Isachsen, Ellef Ringnes Island, Nunavut, Canada on permafrost soil with patterned ground features (unsorted circles) on slightly sloping ground. Photo: F.J.A. Daniëls, July 2005.

Slika 2: Splošni izgled vegetacije razreda Drabo-Papaveretea z vrstami Micranthes foliolosa, Papaver dablianum (rumene pike), Saxifraga oppositifolia, S. cespitosa, mahovi in lišaji. Isachsen, otok Ellef Ringnes Island, Nunavut, Kanada na permafrostu z značilnostmi strukturiranih talnih oblik (nerazvrščeni krogi) na rahlo nagnjeni podlagi. Foto: F.J.A. Daniëls, julij 2005 and cyanobacteria in zonal habitats (cf. Bliss \& Svoboda 1984, Elvebakk 1985, 1997, Aleksandrova 1988, Edlund \& Alt 1989, Bay 1997, Bliss 1997, Lévesque 1997, Matveyeva 1998, 2006, Walker et al. 2005, Vonlanthen et al. 2008, Walker et al. 2011a, 2011b, Daniëls et al. 2013). Low summer temperature is a key factor limiting species richness and cover of vascular plants whereas mosses (Aulacomnium turgidum, Bryum cryophilum, Dicranoweisia crispula, Oncophorus wahlenbergii, Racomitrium lanuginosum), liverworts (Anthelia juratzkana, Gymnomitrion corallioides, Scapania crassiretis, S. simmonsii), and lichens (Cetrariella delisei, Flavocetraria nivalis, Parmelia skultii, P. omphalodes, Siphula ceratites, Stereocaulon rivulorum, Sticta arctica and Thamnolia vermicularis) are locally prominent.

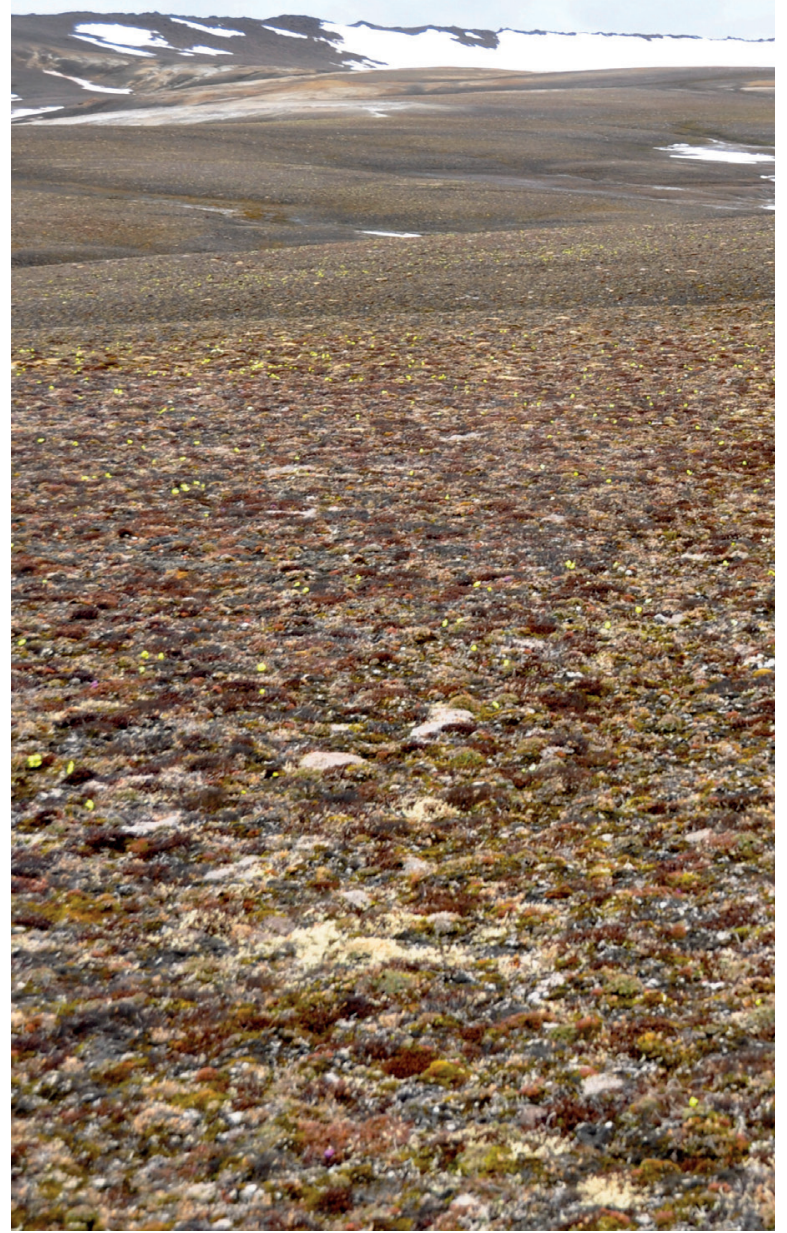

Figure 3: Tundra-like polar desert cushion forb-lichen-moss vegetation near Krenkel Station at $80^{\circ} 38^{\prime} \mathrm{N}$ on Hayes Island, Franz Josef Land, Russian Federation. Photo: D.A. (Skip) Walker, August 2010.

Slika 3: Vegetacija iz polarno puščavskih blazinastih zelišč, mahov in lišajev, podobna tundri, v bližini postaje Krenkel (80³8’ N) na otoku Hayes Island, Dežela Franca Jožefa, Ruska Federacija. Foto: D.A. (Skip) Walker, avgust 2010. 
The number of plant community types is also strongly reduced in the Subzone A and their floristic composition is characterised by a limited number of taxonomically complex vascular plants of the genera Draba and Papaver, and of family Poaceae (e.g. Solstad 2008, Elven et al. 2014) as well as by the broad ecological amplitude of many species. Thorough phytosociological studies of the Subzone A are relatively rare and offer less rigorous syntaxonomic information.

\section{Classification of polar desert vegetation}

Until now the zonal plant communities of the Subzone A (polar desert) were classified from a European point of view within the syntaxonomically complex Arenarion norvegicae Nordhagen 1935 coined to accommodate the vegetation of neutral to base-rich screes of alpine and subalpine belts of boreal mountain ranges of Scandinavia, Iceland and Arctic regions of Svalbard, spanning Low Arctic Subzone and the polar deserts (e.g. Nordhagen 1935, Dierssen 1992, 1996, Daniëls 1994, Valachovič et al. 1997, Daniëls et al. 2000, Möller 2000). The Arenarion norvegicae is classified either in the Androsacetalia (Valachovič et al. 1997) or in the Thlaspietalia rotundifolii Br.-Bl. in Br.-Bl. et Jenny 1926 (Ermakov 2012), both orders belong to the Thlaspietea rotundifolii Br.-Bl. 1948 comprising Euro-Siberian plant communities on screes and related habitats distributed from the lowlands as high as the alpine belt.

The polar desert vegetation was considered as poor fragments of the Arctic tundra vegetation types and, as a consequence, classified within existing arctic-alpine vegetation classes. However new insights gathered in the course of the last two decades during the activities of the CAVM project (CAVM Team 2003, Walker et al. 2005) and new data (e.g. Matveyeva 2006, Vonlanthen et al. 2008, Walker et al. 2011a, 2011b) brought about a conceptual change. Matveyeva (2006) drew attention again to the problem of classification of the polar desert plant communities into existing vegetation classes and pointed upon a possibility of introducing a new syntaxon in its own right at the class level, a viewpoint earlier expressed by Daniëls (2002) and Elvebakk (1985, 1994 , 1997, 2003).

Although the Subzone A lacks exclusive faithful vascular plant species (and probably bryophytes and lichens as well), the plant communities of its zonal habitats (on mesic, fine grained soil, 'plakor' habitats of Russian geobotanists) are considered distinctly different from those of the non-zonal arctic-alpine syntaxa that were assigned either to the floristically very heterogeneous Thlaspietea rotundifolii (see Valachovič et al. 1997), or snow-bed vegetation of the Salicetea herbaceae, or the mire vegetation of the Scheuchzerio-Caricetea fuscae or, finally, to the zonal vegetation of the High Arctic Subzones B and C (Carici-Kobresietea) and the Low Arctic Subzones D and E (Loiseleurio-Vaccinietea) (see also Ermakov 2012). The differences are in the vascular plant flora regarding species composition, plant functional type composition (cushion forbs), life-strategy ('non-aggressive' sensu Yurtsev 1968), and in distribution of the species of wide ecological range, and in the level of gregariousness (growing rather as solitary than in aggregated, often clonal patches). The Arctic polar deserts are also well distinguished from the High and Low Arctic tundras (Subzones B to E, cf. Yurtsev 1968, Aleksandrova 1988). It is therefore that we propose here to recognize the predominant zonal cushion-forb vegetation supported by subxeric to mesic, coarse to finegrained sediments in the lowlands of the Subzone A as a class in its own right. In this concept the class (and the sole order classified within the class) comprise only the zonal plant community types of the Arctic subzone A and corresponding habitats of altitudinal belts of the southern High Arctic subzones. The vegetation cover varies from very open (Figures 1 and 2) to rather closed (Figure 3).

\section{Previous classification of the Papaveretum dahliani}

The core vegetation of the new class to be described (see below) is represented by the Papaveretum dabliani. The Papaveretum dabliani was for the first time mentioned and described by Hofmann (1968) from Svalbard as a nomen nudum; its name was later validated by Dierssen (1992) by publishing a phytosociological table with relevés, character species, and by indication of the nomenclatural type (relevé 1 in Tab. 2 in Dierssen 1992).

Dierssen (1992, see also Elvebakk 1985, Valachovič et al. 1997) classified this association within the Arenarion norvegicae Nordhagen 1935 (Thlaspietalia rotundifoliae, Thlaspietea rotundifoliae). According to Dierssen (1992) and Valachovič et al. (1997), the Arenarion norvegicae comprises Arctic plant communities of base-rich screes and includes the Papaveretum dabliani, Papaveretum radicati, Arenario norvegicae-Brayetum linearis, Phippsio-Cochleariopsietum groenlandicae, Armerio-Silenetum acaulis and Oxyrio-Trisetum spicati. Floristically and ecologically the Arenarion norvegicae was interpreted by Valachovič et al. (1997) in very broad terms, as accommodating vegeta- 
tion on "neutral to base-rich screes of alpine and subalpine belts of boreal mountains in Scandinavia including Iceland and Arctic regions of Svalbard from the low arctic zone to the polar deserts". The Arenarion norvegicae (in sense of original description) is an alliance of calcareous screes in northern Scandinavia characterised by Arenaria norvegica, A. pseudofrigida, Braya linearis, Draba glabella, Elymus alaskanus, Saxifraga aizoides and Veronica fruticans (Nilsen \& Elvebakk 2014). In our view, the Arenarion norvegicae comprises (of all associations listed by Valachovič et al. 1997) only the Arenario norvegicae-Brayetum linearis from Scandinavia and the Papaveretum radicati (Dierssen 1992) from Low Arctic regions of Western Greenland. The other associations of the Arenarion norvegicae (sensu Valachovič et al. 1997) should belong either to the Salicetea herbaceae (Oxyrio-Trisetetum spicati) or to the Cochleariopsion groenlandicae Hadač 1989 (PhippsioCochleariopsietum groenlandicae Hadač 1989).

The Papaveretum dahliani should not be mistaken for the Papaveretum radicati described from Disko, Western Greenland from the Arctic Subzone D (Dierssen 1992). The latter vegetation is also known from anthropogenic (disturbed) and nutrient-enriched sites in Low Arctic Subzones and from boreal Greenland (F. Daniëls, unpublished observations). It may well be that the name-giving species 'Papaver radicatum' in Dierssen (1992), according to the latest taxonomic revision (Solstad 2008, see also Böcher et al. 1978, Porsild \& Cody 1980, Rune 2011), is in fact Papaver labradoricum.

\section{Typification, characteriza- tion and delimitation of the high-rank syntaxa}

Drabo corymbosae-Papaveretea dabliani Daniëls, Elvebakk et Matveyeva clas. nov. hoc loco

Synonyms: Drabo-Papaveretea dablianae Daniëls 2002

(ICPN Arts. 2b, 5, 41a; ICPN = Weber et al. 2000);

Drabo corymbosae-Papaveretea dahliani Daniëls 2013

(ICPN Arts. 2b, 3i, 5); Drabo corymbosae-Papaveretea dabliani Bültmann et Daniëls 2013 (ICPN Arts. 2b, $3 \mathrm{i}, 5)$.

Holotypus hoc loco: Saxifrago oppositifoliae-Papaveretalia dabliani Daniëls, Elvebakk et Matveyeva in Daniëls et al. 2015 (see below).

\section{Saxifrago oppositifoliae-Papaveretalia dabliani} Daniëls, Elvebakk et Matveyeva ordo nov. hoc loco Synonyms: Saxifrago-Papaveretalia dahlianae Daniëls 2002 (ICPN Arts. 2b, 5, 41a).
Holotypus hoc loco: Papaverion dabliani Hofmann ex Daniëls, Elvebakk \& Matveyeva in Daniëls et al. 2015 (see below).

\section{Papaverion dabliani Hofmann ex Daniëls, Elvebakk et Matveyeva all. nov. hoc loco}

Validated name: Papaverion dabliani Hofmann 1968 (ICPN Arts. 2b, 3d) (Hofmann 1968: 29).

Holotypus hoc loco: Papaveretum dahliani Hofmann ex Dierssen 1992 (Dierssen 1992: 197-199).

Diagnostic (character, differential and constant companion) taxa of the Drabo corymbosae-Papaveretea dabliani, the Saxifrago oppositifoliae-Papaveretalia dabliani, and the Papaverion dabliani:

Vascular plants: Alopecurus borealis, Braya glabella subsp. purpurascens, Cerastium arcticum, C. regelii subsp. caespitosum, Deschampsia sukatschewii subsp. borealis, Draba arctica s.l., D. corymbosa, D. micropetala, D. pauciflora, D. simmonsii, D. subcapitata, Festuca baffinensis, Luzula confusa, L. nivalis, Micranthes nivalis, Minuartia rossii, Papaver cornwallisense, P. dahlianum, Parrya arctica, Phippsia algida, Poa abbreviata, Potentilla hyparctica, Puccinellia angustata, Ranunculus sabinei, R. sulphureus, Saxifraga cernua, $S$. cespitosa, S. oppositifolia, S. platysepala, Stellaria longipes s.l. Mosses: Aulacomnium turgidum, Polytrichum piliferum, $P$. strictum, Racomitrium ericoides, $R$. lanuginosum, $R$. panschii, Schistidium frigidum.

Liverwort: Gymnomitrion corallioides.

Lichens: Alectoria ochroleuca, A. nigricans, Catapyrenium cinereum, Dactylina ramulosa, Flavocetraria cucullata, F. nivalis, Parmelia skultii, Sphaerophorus globosus, Sticta arctica, Thamnolia vermicularis.

The character taxa of the alliance, order and class are mainly cushion forbs, and a few grasses and graminoids, such as Draba pauciflora, D. subcapitata, Papaver cornwallisense, $P$. dahlianum, Ranunculus sabinei, $R$. sulphureus, Saxifraga oppositifolia, S. platysepala, Puccinellia angustata and the lichen Parmelia skultii. Constant taxa in most communities comprise: Cerastium arcticum, C. regelii subsp. caespitosum, Micranthes nivalis, Saxifraga cernua, S. cespitosa, Stellaria longipes s.l., Alopecurus borealis and Phippsia algida. Also highly diagnostic is the absence of Carex species, dwarf shrubs and other woody species (Betula, Cassiope, Dryas, Empetrum, Harrimanella, Salix and Vaccinium) and this feature differentiates the polar desert syntaxa against the Thlaspietea rotundifoliae, Salicetea herbaceae, Scheuchzerio-Caricetea fuscae, Carici-Kobresietea and Loiseleurio-Vaccinietea. Additionally, numerous lichens (Alectoria ochroleuca, A. nigricans, Dactylina ramulosa, Flavocetraria cucullata, F. nivalis, Sphaerophorus 
globosus, Thamnolia vermicularis and other chionophobous lichens) and bryophytes (Aulacomnium turgidum, Polytrichum piliferum, P. strictum, Racomitrium ericoides, $R$. lanuginosum, $R$. panschii, and Schistidium frigidum) serve as differential species against scree vegetation of the Thlaspietea rotundifoliae and that of snow-bed vegetation of the Salicetea herbaceae.

The differential taxa of the Arenarion norvegicae against the Papaverion dabliani include: Arenaria norvegica, Artemisia norvegica, Braya linearis, Draba glabella, Elymus alaskanus subsp. borealis, Potentilla nivea s.l. and Saxifraga tricuspidata.

\section{Habitat and distribution}

The vegetation classified as the Drabo-Papaveretea is occurring in regions of very cold climate with mean July temperature below $3^{\circ} \mathrm{C}$ and soil conditions with permafrost and cryoturbation resulting in desert pavements and patterned ground forms. The substrate is formed by carbonate, sandstone or granitic rocks; soil texture varies from gravelly-sandy to fine-grained and loamy. The unique character of the Subzone A or polar desert is further summarized by Walker et al. (2008).

The discussed syntaxa mainly occur in Subzone A, with inclusion of the northernmost fringes of Greenland, the northernmost regions of the Canadian and Russian Arctic archipelagos as well as a small portion of Svalbard (Bay 1997: Fig. 7, Walker et al. 2011b). The distribution of the Drabo-Papaveretea is High Arctic and almost circumpolar, as defined by the distribution of the major diagnostic species. Papaver cornwallisense and $P$. dablianum are mainly distributed in the northernmost parts of the Arctic (Solstad 2008).

\section{Syntaxonomic discussion: Salicetea arcticae vs Drabo-Papaveretea}

The concept of the provisional classification of the High Arctic plant community types of Canada into one class (Salicetea arcticae), including two orders such as the Saxifragetalia oppositifoliae (with four 'alliances' including 'polar desert complex', Papaverion lapponici, Dryado-Salicion, and Cassiopion tetragonae) and the Caricetalia stantis (with only one alliance - the Caricion stantis; Kojima 1991, $1999,2006)$ is problematic from floristic, ecologic as well as phytogeographic points of view. This 'class' comprises vegetation composed of extremely contrasting floras and habitat types: The Dryado-Salicion should be classified in the Carici-Kobresietea, the Cassiopo-Salicion partly within the Loiseleurio-Vaccinietea and the Carici-Kobresietea, while the Caricion stantis probably belongs to the ScheuchzerioCaricetea. Kojima (l.c.) failed to record and report cryptogams (considered as very important in the polar vegetation) in his tabular presentation of the syntaxonomic material, rendering his syntaxa as prime candidates for nomina dubia (see ICPN Art. 37). It is therefore close to impossible to match Kojima's syntaxonomic concepts with ours. No nomenclature types have been assigned to Kojima's (l.c.) units and therefore the concepts are also invalidly published (ICPN Art. 5). Several vegetation types of Kojima's 'polar desert complex' and the Papaverion lapponici contain Salix arctica, Cassiope tetragona, Dryas integrifolia and Carex species, whose absence is a characteristic feature of the syntaxa of the Drabo-Papaveretea.

\section{Extensive delimitation of the Drabo-Papaveretea}

In order to capture the syntaxonomic extent of the new class, here we list the communities (vegetation types) that should be classified within the Drabo-Papaveretea. At this stage we refrain from formal nomenclatural revision of the names of these syntaxa since the listed material requires profound syntaxonomic revision that is to be presented elsewhere.

\section{Canada}

* Puccinellia angustata-Papaver radicatum community (Vonlanthen et al. 2008: Appendix Reference No. 1); Nunavut, Queen Elizabeth Islands, Ellef Ringnes Island, Isachsen; Subzone A; $78^{\circ} 47^{\prime} \mathrm{N}, 103^{\circ} 35^{\prime} \mathrm{W}$; altitude: below $100 \mathrm{~m} ; 14$ relevés

* Saxifraga-Parmelia omphalodes subsp. glacialis community (Vonlanthen et al. 2008: Appendix Reference No. 2); Nunavut, Queen Elizabeth Islands, Ellef Ringnes Island, Isachsen; Subzone A; 78 $47^{\prime} \mathrm{N}, 103^{\circ} 35^{\prime} \mathrm{W}$; altitude: below $100 \mathrm{~m}$; 7 relevés

* Polar desert vegetation (Lévesque 1997: Appendix 5); Nunavut, highlands of Central Ellesmere Island, Subzone $\mathrm{B} / \mathrm{C} ; 78^{\circ}-80^{\circ} \mathrm{N}$; altitude $347-920 \mathrm{~m}$; 20 relevés

* Saxifraga oppositifolia community type (Kojima 1999: Tab. 2, type No.1); Nunavut, Ellesmere Island, Sverdrup Pass; Subzone B/C; $79^{\circ} 08$ N, 80³0' W; altitude: $300 \mathrm{~m} ; 5$ relevés

* Saxifraga caespitosa-Poa arctica type (Kojima 1991: Tab. 4, vegetation type No. 1; see also Kojima 2006); Nunavut, Cornwallis Island, Resolute; Subzone B; 
$74^{\circ} 40^{\prime}-75^{\circ} 00^{\prime} \mathrm{N}, 94^{\circ} 30^{\prime}-95^{\circ} 30^{\prime} \mathrm{W}$; altitude: below $350 \mathrm{~m} ; 8$ relevés

* Saxifraga oppositifolia-Draba bellii type (Kojima 1991: Table 4, vegetation type No. 2; see also Kojima 2006); Nunavut, Cornwallis Island, Resolute; Subzone B; $74^{\circ} 40^{\prime}-75^{\circ} 00^{\prime} \mathrm{N}, 94^{\circ} 30^{\prime}-95^{\circ} 30^{\prime} \mathrm{W}$; altitude: below $350 \mathrm{~m} ; 7$ relevés

* Vegetation of Palisade mesa (Maycock \& Fahselt 1992: Tab. 3, stands 3, 7 \& 9); Nunavut, Ellesmere Island, Sverdrup Pass; altitude: 610-815 m; 3 relevés

* Saxifraga oppositifolia-Festuca baffinensis type (Kojima 1991: Tab. 4, vegetation type No. 3; 5 relevés); Nunavut, Cornwallis Island; Subzone B; rather dry to mesic soil moisture and intermediate soil texture conditions might be included here as well equally as the vegetation type B1 from the synoptic Table 2 of Kojima (2006) described from Bathurst Island by Sheard \& Geale (1983); 7 relevés

\section{Greenland}

* Saxifraga oppositifolia snowbed (Bay 1997: Table 2, SM 1); Northern Greenland, Amdrup Land, Sophus Müllers Naes; Subzone A; 8057’ N, 14²40’ W; 1 relevé

* Saxifraga oppositifolia-Papaver community (Bay 1997: Table 2, SM 2), Northern Greenland, Amdrup Land, Sophus Müllers Naes; Subzone A; $80^{\circ} 57^{\prime}$ N, $14^{\circ} 40^{\prime}$ W; 1 relevé

* Herb barren (Bay 1997: Tab. 2, SM 3); Northern Greenland, Amdrup Land, Sophus Müllers Naes; Subzone A; $80^{\circ} 57^{\prime} \mathrm{N}, 14^{\circ} 40^{\prime} \mathrm{W} ; 1$ relevé

\section{Svalbard}

* Saxifragetum oppositifoliae (Hadač 1946: 152; ICPN Arts. 2b, 3b); no relevé

* Papaveretum dabliani (Hofmann 1968; ICPN Art. 2b); no relevé

* Papaveretum dahliani (Dierssen 1992: Tab. 2); NWSpitzbergen, Liedefjorden; 5 relevés

* Papaveretum dabliani typicum (Möller 2000: Tab. 28, relevés 1-5); Localities Kvikkaa-Liedefjorden, E-Finnluva (Zentral-Germaniahalvøja, Roosflya südl. Korkbekken (Woodforden); 5 relevés

* Papaver dablianum polar desert (Virtanen \& Eurola 1997: Appendix 8); Kjellstromdalen-Agardhdalen region; one column of constancy values of 4 relevés

* Papaver dablianum group (polar deserts) (Virtanen et al. 1997: Table 3); inner Isfjorden; one column of constancy values of 8 relevés

\section{Russia}

* Nanocomplexes of type A and type B (Aleksandrova 1988); Near Nagurskaya polar station, near Zaliv Dezneva, near Glavnyy Val (Franz Josef Land); 10 relevés
* Open aggregations (comitiums) (Aleksandrova 1988: types 3, 5, 6 and 7); Tsentral'naya Susha, Franz Josef Land; 23 relevés

* Cushion forb lichen moss tundra (Walker et al. 2011b: Figures 6, 7 and 8; 10 relevés Krenkel-1, Krenkel 2; relevés 60-69); Franz Josef Land, Hayes Island; 10 relevés

* Deschampsio-Aulacomnietum turgidi (Matveyeva 2006); Severnaya Zemlya Archipelago, southern regions of Bolshevik Island; 18 relevés

* Stellario edwardsii-Hylocomietum alaskani (Matveyeva 2006); Severnaya Zemlya Archipelago, southern regions of Bolshevik Island; 21 relevés

* Papaver polare-Stellaria edwardsii community type (Matveyeva 2006); Severnaya Zemlya Archipelago, southern regions of Bolshevik Island; 3 relevés

* Saxifraga platysepala-Poa abbreviata community type (Matveyeva 2006); Severnaya Zemlya Archipelago, southern regions of Bolshevik Island; 5 relevés

* Saxifraga oppositifolia-Stereocaulon rivulorum community type (Matveyeva 2006); Severnaya Zemlya Archipelago, southern regions of Bolshevik Island; 1 relevé

\section{Acknowledgements}

Thanks are due to D.A. (Skip) Walker, Fairbanks, Alaska, for his initiatives and great efforts in organizing expeditions and fieldwork in the Arctic and discussions that substantially contributed to better understanding of biodiversity of the Arctic vegetation in a circumpolar context. He also kindly contributed one of the photographs. We thank the two reviewers of the manuscript for their excellent comments and suggestions for improvements.

\section{References}

Aleksandrova, V.D. 1988: Vegetation of the Soviet polar deserts. Cambridge University Press, Cambridge, UK, 228 pp.

Bay, C. 1997: Floristical and ecological characterization of the polar desert zone of Greenland. Journal of Vegetation Science 8: 685-696.

Bliss, L.C. 1997: Arctic Ecosystems of North America. In: Wielgolaski, F.E. (ed.) Ecosystems of the world. 3. Polar and alpine tundra. Elsevier, Amsterdam, NL, pp. 551-683.

Bliss, L.C. \& Svoboda, J. 1984: Plant communities and plant production in the western Queen Elizabeth Islands. Holarctic Ecology 7: 325-344.

Böcher, T.W., Fredskild, B., Holmen, K. \& Jakobsen, K. 1978: Grønlands flora. P. Haase \& Sons, København, DK, 326 pp.

Bültmann, H. \& Daniëls, F.J.A. 2013: Greenland data stored in the Arctic Vegetation Archive (AVA) in Münster. CAFF Proceeding Series Report 10: 29-32. 
CAVM Team 2003: Circumpolar Arctic Vegetation Map Scale 1:7,500.000. Map No 1. Conservation of Arctic Flora and Fauna (CAFF)/US Fish and Wildlife Service, Anchorage, AK, US.

Chernov, Yu.I., Matveyeva, N.V. \& Makarova, O.I. 2011 Polyarnye pustyni - na predele zhizni (Polar deserts: At the limit of life). Priroda 9: 31-43. (in Russian)

Daniëls, FJ.A. 1994: Vegetation classification in Greenland. Journal of Vegetation Science 5: 781-790.

Daniëls, F.J.A., Bültmann, H, Lünterbusch, C. \& Wilhelm, M. 2000: Vegetation zones and biodiversity of the North-American Arctic. Berichte der Reinhold-Tüxen-Gesellschaft 12: 131-151.

Daniëls, F.J.A. 2002: Higher syntaxa from the Russian Arctic. In: Raynolds, M.K. \& Markon, C.J. (eds.), Fourth International Circumpolar Arctic Vegetation Mapping Workshop. Open-File Report 02-181 U.S. Department of the Interior, U.S. Geological Survey, Anchorage, AK, US, pp. 60-61.

Daniëls, F.J.A., Gillespie, L.J. \& Poulin, M. 2013: Plants. In: Meltofte, H. (ed.), Arctic biodiversity assessment. Status and trends in Arctic biodiversity. Conservation of Arctic Flora and Fauna, Akureyri, IC, pp. 310-353.

Dierssen, K. 1992: Zur Synsystematik nordeuropäischer Vegetationstypen. 1. Alpine Vegetation und floristisch verwandte Vegetationseinheiten tieferen Lagen sowie der Arktis. Berichte der Reinhold-Tüxen-Gesellschaft 4: 191-226.

Dierssen, K. 1996: Vegetation Nordeuropas. Eugen Ulmer Verlag, Stuttgart, DE, $838 \mathrm{pp}$

Edlund, S.A. \& Alt, B.T. 1989: Regional congruence of vegetation and summer climate patterns in the Queen Elizabeth Islands, Northwest Territories, Canada. Arctic 42: 3-23.

Elvebakk, A. 1985: Higher phytosociological syntaxa on Svalbard and their use in subdivision of the Arctic. Nordic Journal of Botany 5: $273-284$.

Elvebakk, A. 1994: A survey of plant associations and alliances from Svalbard. Journal of Vegetation Science 5: 791-802.

Elvebakk, A. 1997: Tundra diversity and ecological characteristics of Svalbard. In: Wielgolaski, F.E. (ed.), Ecosystems of the world. 3. Polar and alpine tundra. Elsevier, Amsterdam, NL, pp. 347-359.

Elvebakk, A. \& Hertel, H. 1996: Lichens. In: Elvebakk, A. \& Prestrud, P. (eds.), A catalogue of Svalbard plants. Fungi, algae and cyanobacteria. Norsk Polarinstitut, Oslo, NO, pp. 271-360.

Elvebakk, A. 2003: A.1 Arktische Polarwüsten. In: Bohn, U., Neuhäusel, R., unter Mitarbeit von Gollub, G., Hettwer, C., Neuhäuslová, Z., Schlüter, H. \& Weber, H. Karte der natürlichen Vegetation Europas/ Map of the Natural Vegetation of Europe Maßstab/Scale 1.2500000. Teil I: Erläuterungstext mit CD-ROM/Explanatory Text with CDROM. Münster (Landwirtschaftsverlag), BRD, pp. 109-113.

Elven, R. (ed.) 2014: Annotated checklist of the Panarctic Flora (PAF): Vascular plants. Natural History Museum, University of Oslo. http:// nhm2.uio.no/paf/introduction\#section-1 (accessed in November 2014)

Ermakov, N.B. 2012: Prodromus vysshikh edinits rastitel'nosti Rossii. (Prodromus of the higher vegetation units of Russia.) In: Mirkin, B.M \& Naumova, L.G. (eds.) Sovremennoe sostoyanie osnovnykh kontseptsii nauki o rostitel'no-sti. (Modern state of the basic concepts of the vegetation science.) Gilem, Ufa, RU, pp. 377-483. (in Russian)
Frisvoll, A.A. \& Elvebakk, A. 1996: Bryophytes. In: Elvebakk, A. \& Prestrud, P. (eds.), A catalogue of Svalbard plants. Fungi, algae and cyanobacteria. Norsk Polarinstitut, Oslo, NO, pp. 57-172.

Hadač, E. 1946: The plant communities of Sassen Quarter, Vestspitzbergen. Studia Botanica Čechoslovaca 7: 127-164.

Hofmann, W. 1968: Geobotanische Untersuchungen. Ergebnisse der Stauferland-Expedition 1959/1960 8: 1-83.

Kojima, S. 1991.Vegetation and environment of the Canadian High Arctic with special reference to Cornwallis Island. Proceedings of the National Institute of Polar Research on Polar Biology 4: 135-154.

Kojima, S. 1999: Differentiation of plant communities and edaphic conditions in the High Arctic environment, Sverdrup Pass, Ellesmere Island, Canada. Journal of Phytogeography and Taxonomy 47: $17-30$.

Kojima, S. 2006: Phytosociological classification and ecological characterization of high arctic vegetation of Canada with some remarks in relation to vegetation of Svalbard. Memories of the National Institute of Polar Research, Special Issue 59: 38-62.

Lévesque, E. 1997: Plant distribution and colonization in extreme polar deserts, Ellesmere Island, Canada. PhD Thesis, University of Toronto, Toronto, CA, $331 \mathrm{pp}$.

Matveyeva, N.V. 1994: Floristic classification and ecology of tundra vegetation of the Taymir peninsula, northern Siberia. Journal of Vegetation Science 5: 813-828.

Matveyeva, N.V. 1998: Zonal'nost' v rastitel'nom pokrove Arktiki. (Zonation in plant cover of the Arctic.) Proceedings of Komarov Botanical Institute 21: 1-220 pp. (in Russian)

Matveyeva, N.V. 2006: Ratitel'nost' yuzhnoi chasti ostrova Bol'shevik (arkhipelag Severnaya Zemlya.) Vegetation of the southern part of the Bolshevik Island (Severnaya Zemlya Archipelago). Rastitel'nost' Rossii 8: 3-87. (in Russian)

Matveyeva, N.V. \& Zanokha, L.L. 2015. Sosu-distye rasteniya. In: N.V. Matveyeva (ed.) Rasteniya i griby polyarnykh pustyn severnogo polushariya (Vascular plants. In: Matveyeva, N.V. (ed.) Plants and fungi of the polar deserts in the northern hemisphere. St. Petersburg (in Russian). To be submitted.

Mayock, P.F. \& Fahselt, D. 1992: Vegetation of stressed calcareous screes and slopes in Sverdrup Pass, Ellesmere Island, Canada. Canadian Journal of Botany 70: 2359-2377.

Möller, I. 2000: Pflanzensoziologische und vegetationsökologische Studien in Nordwestspitzbergen. Mitteilungen der Geographischen Gesellschaft in Hamburg 90: 1-202.

Nilsen, L. \& Elvebakk, A. 2014: Vegetation of exposed calcareous ridges in central Spitsbergen, Svalbard, Norway. Phytocoenologia 44: $19-29$.

Nordhagen, R. 1935: Om Arenaria humifusa Wg. og dens betydning for utforskningen av Skandinavias eldste floraelement. Bergens Museums Årbok, Naturvidenskapelig rekke 1: 1-183.

Porsild, A.E. \& Cody, W.J. 1980: Vascular plants of continental Northwest Territories, Canada. National Museum of Natural Sciences, National Museums of Canada, Ottawa, CA, 667 pp.

Rune, F. 2011: Wild flowers of Greenland. Narayana Press, Gylling, NO, 350 pp. 
Sheard, J.W. \& Geale, D.W. 1983: Vegetation studies at Polar Bear Pass, Bathurst Island, N.W.T. II. Vegetation - environment relationships. Canadian Journal of Botany 61: 1637-1646.

Solstad, H. 2008: Taxonomy and evolution of the diploid and polyploid Papaver sect. Meconella (Papaveraceae). PhD thesis, University of Oslo, Norway, NO.

Tedrow, J.C.F. 1977: Soils of the Polar Landscapes. New Brunswick, NJ. Rutgers University Press.

Valachovič, M., Dierssen, K, Dimopoulos, P., Hadač, E, Loidi, J., Mucina, L., Rossi, G., Valle Tendero, V. \& Tomaselli, M. 1997: The vegetation on screes - A synopsis of higher syntaxa in Europe. Folia Geobotanica et Phytotaxonomica 32: 173-192.

Virtanen, R \& Eurola, S. 1997: Middle oroarctic vegetation in Finland and middle-northern arctic vegetation on Svalbard. Acta Phytogeographica Suecica 82: 1-64.

Virtanen, R.J., Lundberg, P.A., Moen, J. \& Oksanen, L. 1997: Topographic and altitudinal patterns in plant communities on European arctic islands. Polar Biology 17: 95-113.

Vonlanthen, C.M., Walker, D.A., Raynolds, M.K., Kade, A., Kuss, P., Daniëls, F.J.A. \& Matveeva, N.V. 2008: Patterned-ground plant communities along a bioclimate gradient in the High Arctic, Canada. Phytocoenologia 38: 23-63.

Walker, D.A., Gould, W.A., Maier, H.A. \& Raynolds, M.K. 2002: The Circumpolar Vegetation Map: AVHRR-derived base maps, environmental controls, and integrated mapping procedures. International Journal of Remote Sensing 23: 2551-2571.

Walker, D.A., Raynolds, M.K., Daniëls, F.J.A., Einarsson, E., Elvebakk, A., Gould, W.A., Katenin, A.E., Kholod, S.S., Markon, C.J., Melnikov, E.S., Moskalenko, N.G., Talbot, S.S., Yurtsev, B.A. \& the CAVM Team 2005: The Circumpolar Arctic vegetation map. Journal of Vegetation Science 16: 267-282.
Walker, D.A., Raynolds, M.K. \& Gould, W.A. 2008: Fred Daniëls, Subzone A, and the North American Transect. Abhandlungen aus dem Westfälischen Museum für Naturkunde 70: 387-400.

Walker, D.A., Kuss, P., Epstein, H.E., Kade, A.N., Vonlanthen, C.M., Raynolds, M.K. \& Daniëls, F.J.A. 2011a: Vegetation of zonal patterned-ground ground ecosystems along the North America Arctic bioclimate gradient. Applied Vegetation Science 14: 1-24.

Walker, D.A., Carlson, S., Frost, J.J., Matyshak, G.V., Leibman, M.E., Orekhov, P., Khomutov, A., Khitun, O., Zhurbenko, M., Afonina, O. \& Barbour, E.M. 2011b: 2010 Expedition to Krenkel Station, Hayes Island, Franz Josef Land, Russia. Alaska Geobotany Center, Institute of Arctic Biology, University of Alaska Fairbanks, Fairbanks, AK, US.

Weber, H.E., Moravec, J. \& Theurillat, J.-P. 2000: International Code of Phytosociological Nomenclature. $3^{\text {rd }}$ edition. Journal of Vegetation Science 11: 739-768.

Young, S.B. 1971: The vascular flora of St. Lawrence Island with special reference to floristic zonation in the arctic regions. Contributions from the Gray Herbarium 201: 11-115.

Yurtsev, B.A. 1968: Flora Suntar-Khayata: Problema istorii vysokogornykh landshaftov Severo-Vostoka Sibiri (Flora of SuntarKhyata: Problems of the history of high mountain landscapes of North-East Siberia). Nauka, Leningrad, SU, 235 pp. (in Russian)

Yurtsev, B.A. 1994: Floristic division of the Arctic. Journal of Vegetation Science 5: 765-776. 